IRYNA DYDA

\title{
The role of light in formation of a traditional image of architectural space
}

Abstract

The natural sun light has always been an active factor in formation of local architectural traditions. The sun path impacts the settlement planning, building architecture, and interior zoning, comprising main elements of the architectural identity. In the folk architecture, the light played a symbolic, compositional or decorative role. In particular, eastern orientation of the altar in Ukrainian churches added symbolical lighting effects to the interior, while reflection of the sun light on church domes emphasized the magnitude of the bulding. The tradilional sounh orientation of the front façacte of houses actually resulted in a colorful, irregular composition of the Ukrainian village, contrast coloristic image of buildings and distinctive image of the scenery. Since the architecture of the Eastern European region is closely connected to the landscape,
the main elements, its role in formation of the regional identity should be evaluated appropriately.

Keywords: light, architectural traditions, identity, architectural spase.

Modern scientific researches of the role of light in architecture tion of new technologies for creation of spectacular visual images in the external and internal environment, for visual spatial reconstruction of lost historical objects, for achievement of the emotional expressiveness of public interiors. "Light architecture of the city" and its potential impact on perception of the environment became a popular object of the scientific research along with the traditional material architectural substance. Indeed modern technological capabilities allow using of light in architecture not only for its intended purpose (to light up the space), but also as a tool for function zoning of the space, creation of virtul as a formation of the artistic image of the environment. It appears that archice that architecture has statt of actively cooperte with light of electrical energy.

However, light was also used in architecture in the historical past - for accentuation of forms and colours of buildings, for emotional enrichment of the environment. Although the range of artificial light sources was rather limited at those times, the potential of natural sunlight was used far more intensively. For example, in the time of the summer solstice al longitudinal enfilade of the Amun Temple in Karnak up to the sanctuary was lighted up by the sun that vertically descended to the horizon. In the Egyptian city of Thebes, visual axes of ancient temples were directed at celestial bodies and this was the main factor of their placement in architectural space; the similar principle was applied in Stonehenge that is oriented in the north-eastern direction at the point of sunrise on the day of the summer solstice [1]. In the Temple of Kukulkan, the biggest one in the complex of Maya pyramids in Chichen Itza, having the appearance of 24-meter pyramid with 9 setbacks, the sun rays lighteringup the temple on the days of the autumn and spring solstice create an illusionary image of 37-meter snake made up of seven isosceles triangle that appears to crawl as the sun moves to its head carved in stone [3]. Natural light was also used for accentuation of architectural form with the help of a drop shadow. The angle of sunlight incidence in a certain way impacted the principle of face in some For example, in the Mediterranean region the relief and sculptural decortion on facades of building were well visible to acces of European tion by deep shadows. In northen European regions, where natural lighting was not so intensive, architectural forms of buildings were additionally accentuated by contrast colour (as, for example, in baroque architectural en sembles in Petersburg, projected by Rastreli). In the process of historical evolution every ethnical region developed its own architectural traditions. They manifested themselves in peculiarities of compositional organization of space, in architectural forms of buildings, in the character of their decoration, in usage of a certain colour on facades and roofs of houses. All these characteristics were somehow impacted by the landscape situation, in particular by peculiarities of local natural lighting A traditional regional methodology of organization of architectural space can involve the local landscape in its composition in different ways. Visually In other regions, landscape represents one of equal elements of the architectural composition. It would be logical to assume that increase of the role of landscape in spatial organization of environment leads to increase of the role of natura light in formation of the local architectural identity.

This assumption is confirmed by the example of the traditional architecture of countries of Central and Eastern Europe, particuly Ukraine. For many thousand years, architectur, parious cultures, that successively populted this acture of losely connected with the local landscape. Not suprisingly that con con in ter in planning of setleme ture: in planning of setlements, on adjacent territories and in arch necture of buildings, as well as in the interior. Influence of natural light somew manifested itself everywere. direction of sunlight determined the character of placement of buildings, their architectural plastics, functional organization of space - factors that are important for the architectural identity of a region.

Researchers of the Ukrainian vernacular architecture assert that placement of residential houses in a locality was traditionally linked to cardinal points. There was a general rule that the main façade of a residential house should face the south. Main windows and entrance to the house were located on this southern façade. The main façade never faced the north for at least two reasons. The first objective reason was presented by the climate conditions, since people needed warmth more than coldness. The second subjective reason was rooted in pre-Christian beliefs of ancient Ukrainians, who always associated the north with the country of dead. As a result of realization of this principle, a specific composition of housing development was formed: "The main façade and one side façade of Ukrainian houses are mostly oriented at souther bearings village housing development is characterized by ences areen, are scattered in a picturesue chas on hills and highands." [5]. In conditions of rugged undulting topography, the in settenents were situated in the most low-sloped place places, tit was dificuth to adher to principle of sour paten. It was dificut to adhere to the principle of southern paly linking it with the strat. The fouse, village hompositionally linking it with the street. Therefore, village houses are often turned to the street with their side or rear façade or even at an angle. In this case, buildings form a specific picturesque architectural ensemble. In conditions of flat field, direction of streets was coordinated with orientation of residential houses, so villages had more distinct planning.

Spatial location of churches was also coordinated with cardinal points. Traditionally, the altar faced the east, therefore the main entrance faced the west, while the additional entrance - the south. People avoided making a church entrance facing the north, since this direction was considered to be unfavourable. Y.Taras provides comparative schemes of location of churches in various Ukrainian villages. Their longitudinal axes slightly deviate from the eastern direction to the south and north, forming a small sector [9]. The thing in different seasons, so the eastern directio was identified approximately due to the lack of precision instruments. The temple's axis was directed at the point of sunrise at the moment of construction start. Therefore, the direction of sunlight essentially influenced the ritional spatial composition of the Ukrainian village.

The sunlight also had a principal importance Tor perception of architectural forms and col作 orchics of the arviron a chich to colourstic correpen of archiocturewith londscape: visua com cor colour gamma, or differentiation of a house from the surrounding due to the colour contrast. "Merger "with landscape is demonstrated by the vernacular architecture of Scandinavian countries. For the Ukrainian tradition contrasting differentiation of a house from the natural surrounding is more typical. The colour contrast was mainly achieved by the white colour of walls of the Ukrainian house. The only exception is log buildings in the Carpathians and Northern Polissya, where walls preserved the colour of natural wood. The principal significance of the white colour of the Ukrainian house is proved by the following facts. First of all, houses were painted white irrespective of their construction - solid wood houses, carcass houses and clay houses were always white [6]. This factor differentiates the Ukrainian architectural tradition from for examp the German one, in which various constructive materials on the facade contrast colours. Secondly, in the nation white colour had a higher stacon as an aling house cold be white, while other dwelling house could be white, while other building in the household were covered by clay of different colour shades. R. Radovych in his research asserts that only exterior walls or less frequently - the whole main facade were painted white; in some cases only walls of the residential section were painted white while the rest of the facade remained unpainted [7]. Therefore, only the dwelling house in the household was fully or partially painted white, and this white colour indicated the location of the householder and his family. It is known that the white colour perfectly reflects sunlight. Therefore, in conditions of direct 


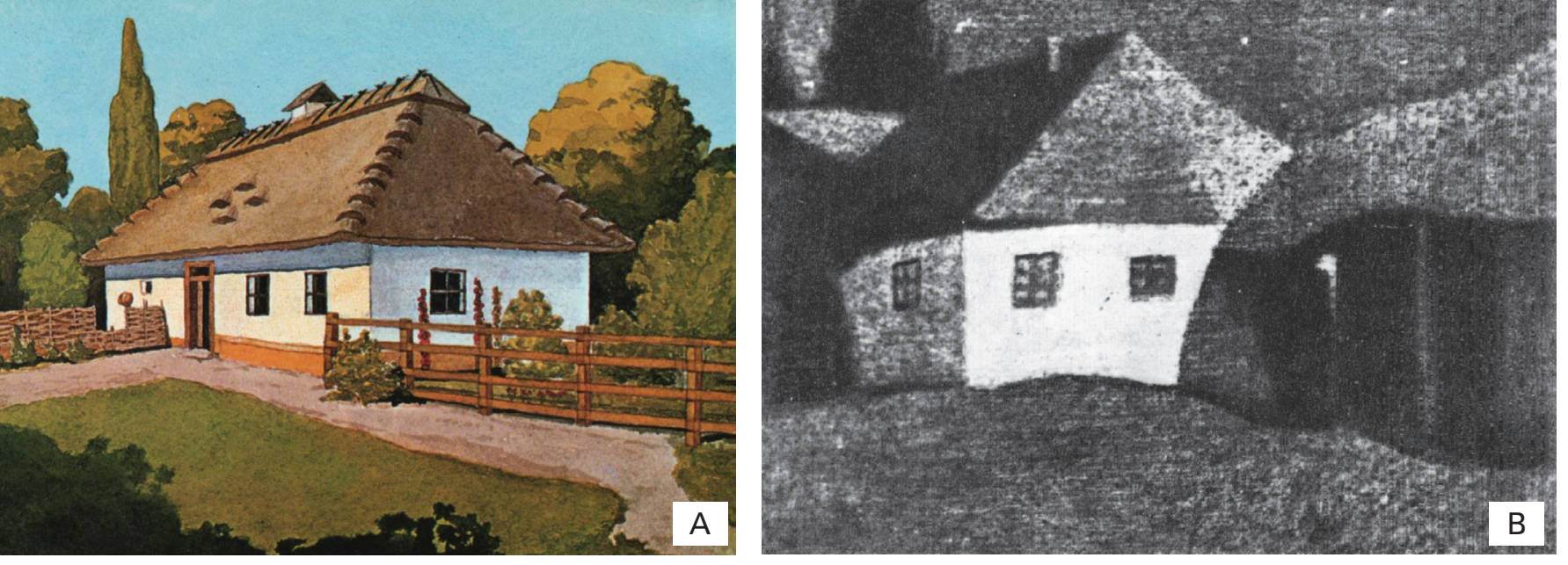

II.1. White walls of rural dwelling house: A - with full sun light (painting by V.Shcherbakivsky); B - with lunar light (painting by O. Kulchytska)

sunlight the white wall of the main southern facade, alongside of other elements painted in various colours, literally "shines in the sun". Thus, the traditional south orientation of the main facade not only ensures good insolation of rooms but also fosters visual identification of the house (il.1).

White wall surface contrasts not only with the external surrounding, but also with other architectural elements of the building. In this case, the sunlight increases the contrast owing to deep drop shadows. The traditional Ukrainian house has a four-slope roof that protrudes beyond walls, creating additional functional space. In conditions of intensive lightning, the roof throws a deep shadow on the façade that accentuates the form of the roof while actively contrasting with the lightened part of the white wall. Therefore, though the area of the visible fragment of the wall reduces, the visual effect is intensified. In the wild nature, the white colour acts as a specific "reflector" helping insects and animals orient themselves in the environment. We can assume that the national tradition adopted the method of using white colour from the wild nature.

Level of lightning of different parts of a living accommodation also determines functional zoning in the traditional folk interialso deter windows were concen the tradtional folk interi-

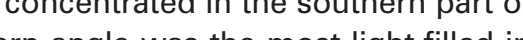
a he interior of a living room. It play the mo " with a big of with a big table, icons on he walls, fanily heirlooms; all famby cele was placed under windows alongside bench was placed under windows alongside the southern wall. It was well exposed to natural light, so all household chores were done here. Northern sectors of the room were badly lighted; a sleeping zone was usually located there. In darkness hours, people used artificial light sources, such as oil lamps or candles. They were not very bright, however lighted windows could be seen from a distance due to light contrast, so they indicated the presence of a settlement on a certain territory.

Therefore, light in the traditional Ukrainian architecture created conditions for visual identification of settlements: natural light in daylight time and artificial light in darkness hours. Natural light had a special influence on the image of Ukrainian churches. Apart from the traditional eastern orientation of the altar, impacting the location of a temple in the settlement, sunlight helped to reveal a specific architectural form of the church. In different ethnographical regions of Ukraine, separate schools of wooden temple architecture were formed. Researchers argue about their exact quantity, however Y. Taras in one of the newest publications on this issue single out 12 such regional schools in the territory of Ukraine. Notwithstanding the variety of architectural forms, they have many aspects in common, such as, for example, domes and galleries encircling the building. Structure of domes of the majority of wooden churches consists of a certain amount of tiers of consequently stacked octagonal vertical prisms and inclined elements - 'cut-off pyramids'. Keeping corresponding proportions, they can create both high as towers and compact densely segmented constructions. In broad daylight deep shadows on tower-like domes chang their location in different times of day, producing new visual effects every time. The more complicated the architectural form of a temple is, the more impressive is the accentuation of this form by a shadow. The symbolic image of this form by a shadow. The symbolic image of al crosses. Although their dimensions by metatively small in anclits lanterns that in sundinformation about the presence a church over a distance. Sunlight produces inpressive visual effect when church domes have metal covering. Very often, no only domes of modern churches are covere with metal sheets, but also walls and galleries of wooden temples. Such tendency leads to destruction of authentic wooden substance of the building due to improper conditions of exploitation, so specialists try to prevent this process. However, notwithstanding the awareness campaign, so far it is impossible to completely eradicate the tradition to cover churches with shiny metal materials. One of probable reasons for this is the expected visual effect produced by the church glittering in the sunlight as if resembling the sun itself.

In bricked churches built in Ukraine, sunlight also intensified the emotional impression from the architecture. For example, churches of $V-V$ th centuries mostly had white walls decorated with relief ornament and gold-plated domes. Their colour pattern continued the principle used in the vernacular domestic architecture, when the most important building was emphasized by the white colour contrasting with the surrounding. While the residential house was the most important in all aspects for agriculture, for a village or a city the church was a centre of spiritual and socia life of a local community. The tradition to build churches in le datory tree planting ang the perimeter of a churchy mancort a for colloce ear a temple and its favourable allornd exposition allowed the sunlight to be composition

Apart from that, natural light reflecting in gold-plated domes helped to make them visible from a far distance. Practically until the $X X^{\text {th }}$ century temples were the highest buildings in a city, therefore reflections of church domes served as certain land beacons for travellers, informing them where a city is located. Gilding of church temples is another example of the folk tradition of making a contrast colour composition. In the external temple architecture, gilding of domes symbolically emphasized the most significant parts of a church, above which they were usually located. Objectively, light always intensifies visual and emotional impression from the gilding. However, the ancient Ukrainian tradition of building churches on high hills in the open green area significantly intensifies the visual impression owing to advantageous ex position of an object. This is also proved by the example of Kyiv city. Although many cities of the world have temples with gold-plated domes, only Kyiv is mentioned as a "city with gold-plated cupolas" in literature descriptions. EvidentIy, gilding of temples in other cities is not exposed so vividly on the background of the densely built-up city area, while Kyiv churches standing on hills produce a strong emotional impression owing to special exposition conditions, when old plated roofs of churches glittering in sunlight gold the main peculiaries of the achitectur image of Kyiv [4].

Apart from lighting of premises, natural light in the interior of Ukrainian temples was also an effective tool of accentuation of its architectural forms. Windows were always located on vertical octagonal prisms of domes of wooden temples, so light, getting inside, lightened up vertical surfaces, leaving sloping surfaces in deep shadows (il.2). Apart from that, ray of the morning sun, penetrating through the window in the altar part of a temple, created an emotional mystical atmosphere of the interior.

In the aspect of the role of light in formation of the traditiona inage of architectural space and its identity, the example of the Ukrainian traditional architecture is illustrative, however not exceptional one. A similar situation can be observed in the traditional architecture of many countries of Eastern and Central Europe, where architectural space from the ancien times was compositionally united with the local landscape, and location of buildings, and temples in particular, always depended on orientation at cardinal points.

Conclusions.

Therefore, natural light and its direction can significantly impact the spatial composition of architectural space, plastic architectural design of separate buildings and even functional organization of interior. These functional oramong those determining the nationatics are artional archion, huge porticing poresideMes Meanwhile, namely natural light is directly connected with a localty, has constant for a given region characteristics, and its proper usage can ensure preservation of a special image of the local architecture in different historical times. The example of the Ukrainian traditional arch tecture confirms that objective features of natural lighting in a certain geographical region influence spatial organization of the living space, its architecture and colouristics - i.e. elements allowing to visually identify ethnographical affiliation of the local architecture. So, preservation of the local architectural identity becomes impossible in conditions of the modern construction without taking into account such characteristics as traditional orientation of facades at cardinal points, meaning of natural shadows for revealing of architectural forms of buildings, need in accentuation of the colour contrast or visa versa, colouristic combination with the surrounding.

Changes that took place in the architectura Che Chentury functiont, constructive and visu between eristics of the environment that historicaly

II. 2. Light in the interior of wooden church in Lebedyn [8]

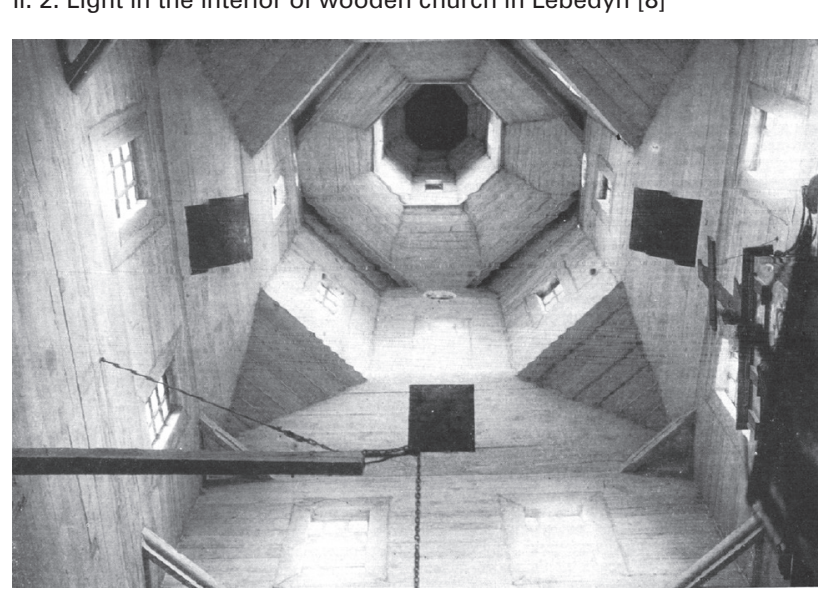


developed in the traditional vernacular architecture and the modern construction industry. At the same time, globalization processes in the world architecture incite us to search methods for preservation of the national identity of architectural space [2] without losing all positive characteristics of the modern construction. Therefore, direct reconstruction of traditional architectural space or its separate elements for preservation of the identity "at any costs" is absolutely out of the question. Taking into account local architectural experience, we need to develop a methodology of formation of modern architectural space on the scientific basis, adhering to traditional compositional principles and historically formed aesthetic priorities. Not all factors impacting formation of traditional visual characteristics of the environment can be equally acceptable for using in the current context. For example, traditional for the vernacular architecture functional organization of internal space, materials and constructions, and related decorative ornaments in most cases already do not meet current social needs and modern constructive possibilities. Instead, such factors as a method of interaction of architecture with local landscape, character of spatial composition of architectural space and principle of its colouristic scheme can be realized irrespective of the architectural style and constructive design of separate buildings - compositional elements of this space. These always relevant, "timeless" factors of formation of traditional features of local architecture include the method of using and broad spectrum of using of sunlight at all levels of architectural assimilation of the environment. Importance of natural light for the architectural identity varies in different local traditions. It depends on the role of the natural landscape in traditional architectural composition.
Architecture of Eastern Europe has old traditions of close cooperation with the natural environment. And sunlight, as one of essential components of this environment, plays a very important (however yet underestimated) role in formation of the traditional image of local architecture. Analysis of peculiarities of the local tradition of using natural light and application of its main principles in newly built constructions in the region will help to preserve national identity in conditions of modern architectural space.

\section{BIBLIOGRAPHY:}

[1] Bunin A., Savarenska T. Istoria gradostroitelnoho iskusstva. T.1, Strojizdat, Moskva, 1979, 496 p., p. 22,23.

[2] Cherkes B. Nacionalna identychnist $v$ arkhitekturi mista, NU " Lvivska politekhnika", Lviv, 2008, 266p.

[3] Chichen-Itza - drevnie misto pyramid Majja $\vee$ Mexici: http://vsviti.com.ua/makepeaple/976 27.04.2017

[4] Dyda I. "Zolotoverkhyj Kyjiv" jak urbanistychnyj fenomen / UAM, Doslidnycki ta naukovo-metodychni praci, No 14, NAOMiA, Kyjiv, 2007, p. 260-267.

[5] Jurchenko P. Narodnoje zylishche Ukrainy, izd. Akademii Arkhitektury SSSR, Moskva, 1941, 88p.

[6] Kosmina T. Silske zytlo Podillia, kinec XIX-XX sт., Naukova dumka, Kyjiv, 1980, 192 p.

[7] Radovych R. Osoblyvosti narodnoho zytla pivdenno-zakhidnoji chastyny Volyni (druha polovyna XIX - pochatok XX stolittia) / Zapysky NTSh, T. CCXXIII, Lviv, 1992. p. 95-104.

[8] Taranushenko S. Monumentalna derevjana arkhitektura livobereznoji Ukrajiny, "Budivelnyk”, Kyjiv, 1976, 334 p.

[9] Taras Y. Ukrajinska sakralna derevjana arkhitektura, ilustrovanyj slovnyk-dovidnyk, NAN Ukrajiny, Instytut narodoznavstva, Lviv, 2006, 584p.

Translation was made by Linguistic Centre (Translation \& Localization Company)

ISO 9001:2009 I Member of Globalization and Localization Association (GALA) State Quality Award Winner of 100 Best Goods and Services of Ukraine 